\title{
The potential of IT to enhance flexibility of domestic practices in a local energy cooperative
}

\section{Citation for published version (APA):}

Verkade, N., Höffken, J. I., \& van Huijkelom, M. (2016). The potential of IT to enhance flexibility of domestic practices in a local energy cooperative. In CIRED workshop 2016 papers [0338] Institute of Electrical and Electronics Engineers. https://doi.org/10.1049/cp.2016.0796

\section{Document license:}

Unspecified

DOI:

10.1049/cp.2016.0796

Document status and date:

Published: 01/01/2016

\section{Document Version:}

Publisher's PDF, also known as Version of Record (includes final page, issue and volume numbers)

\section{Please check the document version of this publication:}

- A submitted manuscript is the version of the article upon submission and before peer-review. There can be important differences between the submitted version and the official published version of record. People interested in the research are advised to contact the author for the final version of the publication, or visit the $\mathrm{DOI}$ to the publisher's website.

- The final author version and the galley proof are versions of the publication after peer review.

- The final published version features the final layout of the paper including the volume, issue and page numbers.

Link to publication

\section{General rights}

Copyright and moral rights for the publications made accessible in the public portal are retained by the authors and/or other copyright owners and it is a condition of accessing publications that users recognise and abide by the legal requirements associated with these rights.

- Users may download and print one copy of any publication from the public portal for the purpose of private study or research.

- You may not further distribute the material or use it for any profit-making activity or commercial gain

- You may freely distribute the URL identifying the publication in the public portal.

If the publication is distributed under the terms of Article 25fa of the Dutch Copyright Act, indicated by the "Taverne" license above, please follow below link for the End User Agreement:

www.tue.nl/taverne

Take down policy

If you believe that this document breaches copyright please contact us at:

openaccess@tue.nl

providing details and we will investigate your claim. 


\section{THE POTENTIAL OF IT TO ENHANCE FLEXIBILITY OF DOMESTIC PRACTICES IN A LOCAL ENERGY COOPERATIVE}

\author{
Nick VERKADE \\ Eindhoven University of Technology - the Netherlands \\ n.verkade@tue.nl
}

\author{
Martijn VAN HUIJKELOM \\ Enexis B.V. - the Netherlands \\ martijn.van.huijkelom@enexis.nl
}

\begin{abstract}
Reporting on a pilot study for a digital platform for monitoring and timing energy usage, the authors use Social Practice Theory to distinguish practices of energy management and practices that consume energy. They conclude that users have to be able to integrate the knowledge gained from the energy management practice into consuming practices to actually make use of this domestic smart grid technology.
\end{abstract}

\section{INTRODUCTION}

In this paper we offer a social-scientific approach in order to study the issue of flexibility of domestic electricity consumption. With growing sense of urgency for a sustainability transition of the energy system, the uptake of renewable generating capacity is picking up at the local level. A transition will challenge the existing electricity infrastructure, and the smart grid is 'hyped' as the solution with significant research investments worldwide [1]. DSOs in the Netherlands have been actively exploring the directions the energy system in transition can take and what the implications for the grid might be. In this paper we report on one of these pilot projects which has been conducted over a one year period. This particular project in the municipality Haaren represents some facets of the transition to a smart and renewable energy system. Local PV capacity has grown through efforts of the local energy cooperative, introducing a daytime feed-in peak of unused electricity, next to the existing consumption peak later in the day. The project entails an IT platform co-created by Dutch grid operator Enexis BV, IT developer Shifft and a local energy cooperative. The platform integrates smart meter data and predictions of local renewable electricity supply and demand to provide users with feedback and advice on timing of use. The question we pose in this paper is: How have users made use of the monitoring and feedback platform and how has this influenced their electricity consuming practices? We approach the insights gained from this smart grid pilot project from the perspective of Social Practice Theory, a social theory which has been applied towards understanding sustainability and consumption. Outlining this strand of social theory and what it means when considering energy consumption is what will follow this introduction. Afterwards the case study will be described more thoroughly, followed by an overview of the results in terms of social practices.

\section{SOCIAL PRACTICE THEORY}

Social theories of practice place the doings of humans center stage: "the basic domain of study of the social sciences [...] is neither the experience of the individual actor, nor the existence of any form of social totality, but the social practices ordered across space and time” [2]. Its rich philosophical and sociological underpinning cannot be done justice in this paper, but we will outline the notions we take from it and how these help us conceive of energy consumption.

Firstly practice theory describes the world we inhabit as something that is routinely made and re-made in practice using tools, discourse, and our bodies [3]. Practices are foregrounded as the building blocks of social life and the recurring performance of these practices is what maintains social structures like institutions, supply chains and infrastructure systems. The energy system is a mesh of practices being carried out by many human actors in different places, and it persists but also changes by recurring performances of these practices. Within the household, practices are the building blocks of the patterns of energy consumption we see today; but at the same time these depend on the continued practices that supply energy.

Secondly, every performance of any practice is a combination of elements, consisting of bodily and mental activity, things and resources, practical know-how, emotions and motivations [4]. These elements find their origin in other practices of producing and teaching and in cultural standards, expectations and rules. By drawing upon these elements, every single performance of a practice is social. This is important in understanding consumption, because now the practices in which resources are used are both individually specific and socially informed and constrained. These two general understandings of social practice theory lead to the following understanding of domestic energy consumption.

\section{CONSUMPTION THROUGH PRACTICES}

In performing daily routines of domestic practices, consumption of resources like food, water or energy is a by-product: "... from the point of view of a theory of practice, consumption occurs within and for the sake of practices.” [5]. Energy, and electricity in particular, is an indispensable but mostly invisible background element of the practices through which it is consumed. Especially 
in the most-developed European countries the quality of electricity supply is so successful [6], its availability is rarely something we consider. The experienced comfort of domestic life relies heavily upon the stable supply of these utilities, something that becomes painfully apparent in case of breakdown. Electricity and most of the delivering infrastructure are physically hidden from view, and the practices through which it is consumed are often part of inconspicuous routines and habits [7]. This invisibility might prove a challenge in a future energy system that arguably relies on its users being smart, responsible and engaged in its functioning [8]. In the Netherlands grid operators are gradually introducing smart meters to all households, and a fast increasing amount of energy monitoring devices and apps is on offer [9]. These, and more integrated innovations like Home Energy Management Systems (HEMS) are supposed to make energy more visible again, and are likely to become part of a renewable and smart energy infrastructure in some way.

So, while recognizing that in most activities that make up energy consumption, energy itself is a backgrounded and invisible material element, there are some practices in which it is a more visible or central element. This distinctive category of practices is what we call energy management practices, or e-practices. Domestic epractices are aimed at acquiring, measuring and managing energy, and together they form a bundle of practices through which the domestic energy flow is organized. Beyond the classic captive consumer role [10], the householder can take up a number of e-practices in which energy is more regularly and actively engaged with. This could simply be routinely taking meter readings, choosing the cheapest or greenest supplier, or replacing old appliances to enhance energy efficiency. But with the advance of decentralized electricity generating technologies and the growing sense of urgency for an energy transition, a broader range of epractices is being taken up. Solar panels and wind turbines provide the technological elements for new epractices to generate electricity. Information technologies like smart meters, energy monitoring apps and online platforms are elements for new e-practices of tracking electricity use and generation and consumption management. The performance of these e-practices does not reduce energy consumption in itself. This is only established when these e-practices are linked to the range of practices that do consume energy. We imagine these links as whatever meaning, knowledge or material is produced by the e-practice, becomes an element of another (consuming) practice.

Summarizing, smart grid innovations like energy monitors or flexible pricing are only one element in energy management practices which the householder is aimed to carry on. On top of that, the product of this energy managing practice is a different understanding of how or when to use energy, which in turn has to be applied as element in consuming practices to lead to any changes in consumption patterns. Furthermore, a practice theoretical approach to energy use means that we recognize that energy consumption is only as malleable and flexible as the actual practices through which energy is used, and these practices are obdurate in many ways.

\section{THE PILOT STUDY}

March 2015 marked the beginning of a one-year pilot study for the online platform Together Smart with Energy for feedback and advice on energy consumption, already described shortly in the introduction. About one hundred members of the local energy cooperative Duurzame Energie Haaren (DEH) signed up for this pilot, which gave them access to a website and a smart phone app. The P1-device developed by DSO Enexis gathered and communicated household consumption data from the smart meter, and this data was accumulated on the cooperative level. Three main goals and functions can be attributed to the platform: provide contextualized feedback to domestic users with comparison to peers; provide a communication platform for cooperative members to organize, learn and bond; provide timing-ofuse advice to enhance domestic use of self-generated solar PV electricity. In terms of our practice theoretical approach, these functions of the platform were designed to be elements of three practices 'in the making': monitoring of energy consumption, applying timing-ofuse advice, and communicating with other participants. Over the course of the pilot, several methods of data collection and analysis have been applied. Quantitative analysis of the consumption patterns was conducted to monitor demand shifts and changes. Surveys among cooperative members were held before and during the pilot, to take inventory of their reasons for joining and their experiences in using the platform. Personal interviews and one group interview provided richer information on how users engaged with the platform, as well as their ideas about their role as citizens in the energy transition. Finally, the researchers were part of the periodic meetings of the pilot organization, where issues and plans for the platform were discussed. At the time of writing the pilot study is still in progress and data collection and analysis incomplete, but based on the results so far we will next further explore two e-practices: monitoring and timing of use.

\section{Monitoring}

The main aim of the monitoring function is to help users reduce their energy consumption by making it visible and ranking it relation to their peers. Especially inconspicuous consumption by electronic equipment that is always on or in stand-by is targeted, but tracking realtime usage can also illuminate high-consumption devices to the user. The periodic ranking is based on the savings that have been realized over that short period, driving a continued incentive for the users to find savings. During 
the pilot one week was appointed to reduce inconspicuous consumption between 1 a.m. and 3 a.m. as much as possible. In this week 79 out of 104 participants managed to cut back electricity demand, totaling a combined reduction from the benchmarked $8.195 \mathrm{~W}$ to $7.146 \mathrm{~W}$. In the case that participants do not make much use of the monitoring function, it is often because they claim to already use relatively little energy. This claim is not uncommon among participants, many ageing about 50 years or more, and being more energy-minded as early members of a local energy cooperative. Over longer periods it has been found that many users decreasingly take note of their real time consumption numbers. At first users can gain initial insight in the numbers and patterns of their consumption and production patterns, which do give some impetus for taking energy reducing measures. But many participants indicate that after some time and having taken the measures they deem feasible, their interest in real time monitoring declines.

\section{Timing of use}

The online platform incorporates functionality to improve self-consumption of solar PV generated electricity within the cooperative. Users can see data on the self-sufficiency of the cooperative: how much electricity has been taken from the grid and how much has been fed back. Additionally they receive timing-ofuse advice based on predictions about consumption and PV generation within the cooperative. When checked, this advice indicates if around that time any solar electricity was available for use; if not, a measure to reduce grid-fed consumption was provided. Participants checking this advice regularly were envisioned to find ways to reduce grid-fed consumption and increase consumption of cooperatively generated electricity. The overall conclusion for this aspect of the platform was that it produced very little results, for a variety of reasons. Although individual efforts towards self-usage are possibly obscured at the aggregated level of measurement, the goal of improving self-use at the cooperative level was far out of reach. The different reasons fall into two broad categories: (1) users are not incentivized financially to improve self-usage, and even when other benefits are perceived, they do not outweigh the costs; (2) users see only limited options to actually make use of the solar PV they produce during the day. Regarding (1), one question for this pilot was to see if non-financial benefits could also play a role in the promotion of timeshifting electricity consumption. The only incentive in play is an appeal to the emotional value of a self-sufficient community. The participants hold an understanding that using their own generated solar electricity is the right thing to do, and in this case for many this includes the grid management point of view. Despite this, participants reported that their non-financial reasons for timeshifting have to be weigh up to effort it takes to apply them in practice. On top of this, financial mechanisms like net-metering and day/night tariffing also factor into the equation. In terms of financial benefits, net-metering effectively takes away the need for self-use and does not lead solar PV owners to question their consumption pattern. Day/night tariffs are a measure to flatten consumption patterns to the benefit of large scale energy producers, by shifting usage to the night. Pilot participants with this double metering system are faced with competing incentives, and for now many perceive most benefits in using the night tariffs as much as possible. Reason (2) points out the limited possibilities they see to shift activities from peak moments to the solar peak period. Using the washing machine, the drying tumbler and the dishwasher are very regularly named first as flexible practices which could be shifted in time. Less often mentioned are the charging of battery devices and using household appliances like the vacuum cleaner. These only represent a small portion of household electricity usage, and even these practices are in reality not so flexible as they are part of the heavily routinized flow of domestic practices.

Put together, shifting consuming practices in time takes some effort, and the non-financial benefits the participants do see in this do not weigh up to this effort. This balance is further shifted by financial benefits that effectively compete with the reasons for timeshifting. Even with strong reasons for applying the timing-of-use advice in practice (even including financial benefits), the amount of consuming practices that could sensibly be shifted to solar power periods is limited.

\section{CONCLUSION}

Using a practice theory perspective, we have argued for a distinction between practices in which electricity is consumed as a backgrounded element and energy management practices in which energy is a visible and focal element. In a more sustainable and smart energy system the domestic energy user is often portrayed as a more active participant who utilizes renewables and IT to be more self-sufficient, efficient and sustainable [11]. This would mean that users of these technologies have meaningful and effective ways of applying the output of their energy managing practices (e-practices) to change the practices through which they use energy. Energy management technology generally provides information on energy availability, usage, price or the sustainability of consumption. Users turn this information into knowledge by combining it with know-how on what the information means and how it could be applied, as well as meanings of why this application would be good or beneficial. The output of e-practices is an understanding, know-how or motivation to act on the household's energy consumption. This understanding could then be an element of consuming practices; but these consuming practices have their own, (possibly competing) understandings, timing, rhythms and motivations. These elements of consuming practices are social in the sense 
that they are mostly not fully controlled, established or chosen by the individuals in the household. Organizational routines, natural rhythms, culturally established standards and expectations all determine the routines that are established in the household. Changes in consumption patterns are realized only if new understandings of timing can challenge and feasibly become part of energy consuming practice(s).

In the case study, the understanding that comes from the practice of monitoring is how well the household is performing, and that using less energy is beneficial. This understanding has been applied to change consuming practices, especially those where it costs little effort or comfort. Most gains were made by turning off equipment at times when it was not used in any practice, which does not really challenge established routines and expectations of comfort. Higher reduction goals increasingly challenge the way consuming practices are performed: the technology used may be challenged in efficiency; the need for comfort that the practice provides is questioned. The output of the timing of use practice is an understanding, know-how or motivation for when to use energy and why. Pilot participants were not able to link this understanding into energy consuming practices, despite the positive motivations for timeshifting that were part of this understanding. New understandings about timing of use did not match with the 'ways of doing' of consuming practices. As said before, these ways of doing are relatively inflexible because they are established in a larger mesh of organizational practices, cultural practices, rulemaking, material limits and natural rhythms. The conclusion we draw from this is not that this makes the shifting of consuming practices in time unfeasible; it is that changes in consumption patterns cannot be expected by simply introducing smart energy technologies in the household without considering the routinized practices which they aim to change.

\section{RECOMMENDATIONS}

Here we will take a first step towards drawing lessons from our perspective on energy consumption and epractices. Advice on the timing of energy usage in itself may not give the user enough practical cues for action, and the average user has limited knowledge of what their energy consumption consists of. Therefore it may be needed to help out in making the link between the information the e-practice provides and consuming practices. Point out benefits where they are and point out where to apply the information and understanding that is produced. Refer to concrete energy consuming practices and design or foster those elements that support a more flexible practice. Keep in mind and challenge the obduracy of consuming practices, because the way they are performed depends not just on the technology, but also in their cultural embedding and the organization of the connected social practices. Besides this assistance in learning, the benefits should be clear too. Regarding the timing of use and promoting self-use of solar power, competing benefits were in play. Whether or not a financial benefit is essential to coerce timeshifting we cannot say because this case study does show that participants subscribed to non-financial motivations for it. However, a clear financial benefit (or averted loss) in the form of tariffing structure and the rules for domestic solar PV generation will provide stronger support to enhance flexibility of energy consumption.

\section{REFERENCES}

[1] G.P.J. Verbong, S. Beemsterboer, F. Sengers, 2013, "Smart grids or smart users? Involving users in developing a low carbon electricity economy", Energy Policy, Vol. 52, 117-125.

[2] A. Giddens, 1984, The Constitution of Society: Outline of the Theory of Structuration, Univ of California Press, Oakland, USA.

[3] D. Nicolini, 2012, Practice theory, work, and organization: An introduction, Oxford University Press, Oxford, UK.

[4] T.R. Schatzki, 2002, Site of the Social: A Philosophical Account of the Constitution of Social Life and Change, Penn State Press, University Park, USA, [4] A. Reckwitz, 2002, "Toward a Theory of Social Practices: A Development in Culturalist Theorizing", European Journal of Social Theory, Vol. 5, 243-263.

[5] A. Warde, 2005, "Consumption and Theories of Practice", Journal of Consumer Culture, Vol. 5, 131153.

[6] CEER, 2015, CEER Benchmarking Report 5.2 on the Continuity of Electricity Supply, Brussels, Belgium.

[7] E. Shove, 2003, Comfort, cleanliness and convenience: The social organization of normality, Berg Oxford, Oxford, UK.

[8] M. Goulden, B. Bedwell, S. Rennick-Egglestone, T. Rodden, A. Spence, 2014, "Smart grids, smart users? The role of the user in demand side management", Energy Research \& Social Science, Vol. 2, 21-29.

[9] MilieuCentraal, 2016, Energieverbruiksmanagers, 2016, www.energieverbruiksmanagers.nl/.

[10] G. Walker, N. Cass, 2007, "Carbon reduction, 'the public' and renewable energy: engaging with sociotechnical configurations", Area, Vol. 39, 458-469.

[11] Y. Strengers, 2014, "Smart energy in everyday life: are you designing for resource man?", Interactions, 4, 2431. 